\title{
Feministiese hermeneutiek as kritiese teorie
}

\section{Yolanda Dreyer \\ Navorser: Departernent Nuwe-Testamentiese Wetenslup (Afd A) \\ Universiteit van Pretoria}

\begin{abstract}
Feminist hermeneutics as critical theory

The aim of this study is to describe the main characteristics of some approaches within feminist hermeneutics. The following approaches have been identified by Carolyn Osiek: 'rejectionist', 'revisionist', 'sublimationist' and 'liberationist'. To these approaches an epistemology of participation is added. Feminist hermeneutics is seen through the lense of the critical theory of Jargen Habermas. The result poses an alternative to a positivistic approach to Scripture. Some contributions of feminist hermeneutics to church and society are identified.
\end{abstract}

\section{INLEIDING}

Normaalweg word feministiese hermeneutiek verstaan as 'n faset van kontekstuele teologie, en in die besonder die bevrydingsteologie. In die kontekstuele teologie word die Bybel bewustelik vanuit en in terme van die sosiate wêreld van die hedendaagse leser geinterpreteer. Hierdie aangeleentheid het nie altyd in die hermeneutiek uitdruklik aandag gekry nie. Die historiese kritiek, byvoorbeeld, het wel die verband tussen die vorm van die teks en die sosiale lokaliteit (Sitz im Leben) daarvan raakgesien, maar nie die teks" benader vanuit die negatiewe ervaring van mense wat deur sosiale omstandighede veroorsaak is nie. In die kontekstuele hermeneutiek word uitdruklik aanvaar dat die huidige leser van die Bybel die teks benader vanuit sy of haar kontemporêre ervaring. Spesifieke ekologiese, kulturele en politieke omstandighede speel in op die lees van die Bybel. In die bevrydingsteologie is dit die ekonomies behoeftige en die polities onderdrukte wat die uitgangspunt in die hermeneutiek is. Die feministiese teologie het die negatiewe ervarings van vroue begin uitlig. - Waar die 'tradisionele teologie' dikwels gerig was op die 'bekering' van die ongelowige, is die bevrydingsteologie gerig op die identiteitlose mens, die gemarginaliseerde.

Hierdie artikel is 'n verwerking van die resultate van 'n deel van hoofstulkke 3 en 4 van die DDproefskrif 'Pastorale interaksie met vroue: 'n Prakties-Teologiese begronding', ingedien en anvaar as deel van die vereistes vir die DD-grand (1998), Departement Praktiese Teologie, Fakulteit Teologie (Afd A), Universiteit van Pretoria, onder leiding van prof dr T F J Dreyer (promotor) en prof dr A G van Aarde (mede-promotor). 
Rosemary Ruether (1983:41-45, 216-232) wys drie groot rigtings in die kontemporêre feminisme uit:

* Die 'liberale feminisme' fokus op politieke hervorming, gelyke regte en verbeterde werksomstandighede. Dit aanvaar dat die Westerse materialistiese sisteem hervorm kan word as hierdie sake reggestel word. Die inherente leemte van hierdie benadering is dat dit nie gerig is op die ontmaskering van 'n hiërargiese sisteem wat gebou is op sosiale klassestratifikasie en manlike magsdominansie nie. Regstellende aksie wat vroue gelyke werkgeleenthede gee en hulle selfs in bestuursposte plaas, fokus nie as sodanig daarop om die negatiewe ervaring van vroue en die skade wat 'n skeefgetrekte hiërargie kan veroorsaak, teen te werk nie. 'n Praktyk wat slegs die gelykheid van vroue in die $\infty \mathrm{g}$ het, het myns insiens nog nie die kern van die probleem raakgesien nie.

* Die sosialistiese of Marxistiese feminisme meen dat volle gelykheid vir vroue slegs op die terrein van arbeid en produksie bereik kan word. Die leemte van hierdie benadering lê daarin dat die probleme wat daar byvoorbeeld in die patriargale institusionalisering van die gesin kan lê, geen aandag kry nie. In die praktyk loop die sosialisme uit op 'n dubbele werklas vir vroue. Vroue aanvaar nie net verantwoordelikheid vir 'n volle bydrae tot produksie in die samelewing nie, maar is ook alleen verantwoordelik vir die huishoudelike arbeid.

* Die 'romantiese feminisme' lê klem op die verskille tussen man en vrou. Hierdie benadering sien wat vroulik is as inherent hoër en beter as die manlike. Dit verheerlik sogenaamde 'vroulike eienskappe', soos byvoorbeeld sensitiwiteit, kreatiwiteit, intuisie en liggaamlikheid, wat onderdruk word deur patriargale dominansie. Die doel van hierdie benadering is om die manlike wêreld te transformeer tot die hoèr vroulike ideaal. Die leemte daarvan is dat dit geneig is om die oplossing van negatiewe ervaring te sien in 'n vroulike utopie. Dit lei daartoe dat hierdie vroue uit die samelewing onttrek en nie in die samelewing self die kragte agter die negatiewe ervaring help blootlê, sodat dit teengewerk kan word nie.

Carolyn Osiek (1997:958) onderskei nog 'n vierde moontlikheid. Sy noem dit 'n 'bevrydings-hermeneutiese feminisme'. In hierdie benadering word die beste van die bogenoemde rigtings bymekaar gebring: die menslike ontwikkeling en gelykheidstrewe van die liberale feminisme, die sosiale kritiek en strewe na 'n regverdige samelewing 
van die sosialistiese feminisme en die strewe na dieper menslike waardes van die romantiese feminisme. 'n Ware bevrydende feminisme sal die swakhede van die vorige drie standpunte kan oorstyg. Die fokus op die ervaring van die onderdruktes sal die saak waarom dit gaan, kan bevry van die liberale feminisme se leemte, naamlik die neiging om nie die probleme wat verwronge sosiale stratifikasie veroorsaak, raak te sien nie. Die visie van 'n nuwe samelewing sal die negatiewe uitwerking van patriargalisme verdiskonteer - iets wat die sosialistiese feminisme nie gedoen het nie.

Indien bogenoemde problematiese elemente in die feministiese strominge uitgeskakel kan word, kan die insigte wat soveel bygedra het tot die bewuswording van vroueervaring, vrugbaar gebruik word in verskeie fasette van die kerk se werk. In die kerk word só gehandel en gekommunikeer dat die mens 'n outentieke lewe voor God kan lei - wat ook beteken dat negatiewe ervaring in die kerk en in die samelewing teengewerk sal moet word. Die norme aan die hand waarvan so 'n praktyk sal geskied, hou verband met Skrifbeskouing.

Op die terrein van die feministiese hermeneutiek wil Osiek (1997:957) ook die Bybel as norm ernstig neem. Daar bestaan verskeie wyses waarop feministiese teoloe die Bybel interpreteer. Hierdie afdeling van die artikel word ingerig veral na aanleiding van die werk van Carolyn Osiek. Osiek (1997:957) se corsig plaas die ervaring van vroue in die sentrum. Die bespreking geskied aan die hand van drie van haar vooronderstellings:

* Die Bybel word beskou as deel van gelowiges se alledaagse geskiedenis. As sodanig is die Bybel 'n instrument van mag waarmee geloofsgemeenskappe moet rekening hou sodat so 'n Skrifgebruik kan verander.

* Die hermeneutiek van die Bybel is nie 'n aangeleentheid wat slegs op abstrakte vlak plaasvind nie, maar behoort te geskied in voortdurende interaksie met die ervaring van die mense in die geloofsgemeenskappe.

* Bybeltekste het binne 'n spesifieke tradisie onstaan en lewe steeds voort binne 'n tradisie. Die spesifieke tradisie mede-bepaal hoe mense hulle werklikheid in die lig van 'n betrokke teks verstaan en die teks word weer verstaan in die lig van die besondere situasie waarin mense hulle bevind. Ons is deel van die geskiedenis en ons is deel van die proses waar geskiedenis gemaak word. 'n Kontemporêre hermeneutiek moet daarom net so sterk aan die ervaring van mense aandag gee as aan die teorie van eksegese. 
Op die terrein van die eksegese, domineer die histories-kritiese metode reeds bykans drie eeue. Deesdae word wyd aanvaar dat hierdie metode beperkings het en vooroordele vertoon. Hoewel steeds belangrik, kan die historiese kritiek nie meer as die enigste geldige metode beskou word nie. Dit is nie meer die absolute kriterium vir alle interpretasie nie. Deesdae bestaan daar 'n verskeidenheid van metodes. Hierdie feit weerspieèl die werklikheid dat die interpretasie van die Bybel nie in isolasie van die sosiale en intellektuele wêreld van die eksegeet kan gebeur nie. Hierdie wêreld is te pluriform en kompleks om vasgevang te word binne die beperkte grense van die histories-kritiese eksegese.

Sinvolle aanpassings kan gemaak word deur die historiese wetenskap aan te vul met insigte vanuit die sosiale wetenskappe (kyk Elliott 1993). So 'n aanpassing bring mee dat feministiese eksegete Bybelinterpretasie beskou as bruikbaar om die waarde van vroue op alle terreine van die samelewing te bevorder. Wanneer vroue in die kerk bewus word van manlike dominansie en ook bewus word dat die Bybel as instrument gebruik is en steeds gebruik word om 'n patriargale struktuur in stand te hou wat vroue-ervaring voorskryf, inperk en selfs negeer, kan hulle begin reageer op die neerdrukkende situasie. Daar kan onder andere vyf moontlike reaksies binne die feministiese hermeneutiek onderskei word. Dit kan beskryf word as 'rejectionist', 'loyalist', 'revisionist', 'sublimationist' and 'liberationist' (kyk Osiek 1997:957-966). Ek gee vervolgens aan elkeen van hierdie reaksies aandag.

\section{2. 'N SKRIFBESKOUING VAN VERWERPING}

Een van die moontlike reaksies is dat vroue die Bybel verwerp omdat dit nie meer bruikbaar geag word nie. Daarmee saam word die hele godsdienstradisie wat die Bybel verteenwoordig, as onaanvaarbaar beskou. So 'n standpunt aanvaar dat daar aan Bybel en tradisie niks te redde is nie. Die rede hiervoor is dat patriargalisme gesien word as 'n inherente korrupte element van die boodskap van die Bybel en die Joods-Christelike tradisie. Daarom moet dit totaal verwerp word. Mary Daly $(1973,1979)$ is 'n eksponent van hierdie radikale standpunt. Dit is 'n siening wat lei tot 'n nuwe dualisme waarin manlikheid die bose verteenwoordig en vroulikheid die goeie. Dit staan 'n rolleverwisseling in die hiërargie voor. Die konsekwensie is dat 'n hiërargie gehandhaaf word. Die hermeneutiek in hierdie benadering is een van 'radikale separatisme'. Volgens Osiek (1997:961) bestaan die grootste leemte van hierdie rigting daarin dat dit geen wortels het nie. Daar is bykans geen band met of die historiese verlede (Bybel en tradisie) of met die teenswoordige dinamiek van die samelewing nie. Die enigste 'wortels' is ' $n$ idilliese tydperk in die pre-historiese verlede toe godinne aanbid is. Die enigste (wan)hoop is dié van 'n (utopiese) eskatologiese toekoms waar die bose (manlike) oorkom sal word deur die goeie (vroulike). 


\section{3. 'N POSITIVISTIESE SKRIFBESKOUING}

Hierdie reaksie is presies die teenoorgestelde van die vorige. Die Bybel hoef nie 'gered' te word nie. Die Bybel word sondermeer beskou as Woord van God en in wese probleemloos. Die Bybel is uitdrukking van God se gesag, dit skryf voor en die mens moet gehoorsaam. Dit is onmoontlik dat die Bybel as Woord van God onderdrukkend kan wees. As dit so beleef sou word, lê die fout by die interpretasie, nie in die Bybel nie. Die Bybel bedoel die beste vir mense, maar dit kom nie altyd ooreen met die standaarde van die hedendaagse kultuur nie. Met ander woorde, as die Bybel iets sou sê wat volgens vandag se sensitiwiteit nie 'polities korrek' sou wees nie, moet die mens steeds nie aan die goeie bedoeling van die Bybel twyfel nie, maar daarvolgens skik. Die Bybel staan wel 'vryheid' voor, maar volgens God se wil en plan, nie volgens wat die mens wil nie. 'Ware vryheid' is verlossing vanuit die sonde en het nie te doen met sosiale aktiwiteite nie. Tog is dit nie die bedoeling van die Bybel dat mans en vroue in onderdrukkende verhoudings van dominansie en in 'n magstryd sal lewe nie. Sulke verwronge verhoudings is ' $n$ manifestasie van die sondige menslike natuur.

Dit is egter 'n vraag wat eksponente van hierdie benadering sou sê oor die eksplisiete ondergeskikte posisie van vroue wat in die Bybel wel betuig word. Twee interpretasies word in hierdie verband aangetref (kyk Osiek 1997:961-962). Die een is dat die Bybel dit nie regtig sê nie. Goeie eksegese moet maar net die ware bedoeling van die Bybel na vore bring en die verkeerde sosiale houdings moet verander word om te pas by die bedoeling van die Bybel, naamlik een van wedersydse respek. Die tweede interpretasie gaan daarvan uit dat manlike hiërargie God se wil is omdat dit in God se openbaring voorkom. Daarom moet dit aanvaar word as God se voorskrif vir 'n ordelike samelewing. Ongehoorsame mense wat mag misbruik, moet hulle eenvoudig bekeer. Hierbenewens sal dié standpunt dit beklemtoon dat ondergeskiktheid net binne die gesin geld en nie vir die breë samelewing nie. Om die standpunt oor die gesin te sien in terme van die verhouding dominansie-onderdanigheid, is om die Bybel verkeerd te lees. Die Bybel het noodsaaklike leierskap en volgelingskap in die oog. Dit is die manier wat God verorden het om eenheid en harmonie in die samelewing te bewerkstellig. Mans se posisie in die hiërargie verminder nie vroue se menswaardigheid nie. As mans maar net met liefde heers, verskaf dit vryheid vir vroue om hulle Goddelike bestemming te bereik.

So 'n positivistiese Skrifbeskouing is vir konserwatiewe vroue die antwoord op die vraag watter plek en rol hulle binne die geloofsgemeenskap moet inneem en vervul. Eksponent van hierdie benadering is Susan Foh (1979). Nie net is die positivisme, gebou op 'n objektiwiteitsideaal en 'n kousaliteitsbeginsel, die probleem nie; dit neem eenvoudig nie die post-moderne eis om simmetriese kommunikasie in ag nie. Die objektiwiteitsideaal bestaan daarin dat vroue gedwing word om die sogenaamde 'objektiewe waarheid' van die Bybel sondermeer te aanvaar. Die kousaliteitsbeginsel mani- 
festeer daarin dat vroue aan 'n determinisme uitgelewer word, want dit sou 'God se wil' wees dat hulle onderdanig moet wees. Hierdie benadering bevat geen bewusmakingsproses wat die loop van die geskiedenis met betrekking tot negatiewe vroue-ervaring wil verander nie. Hierbenewens vind ons 'n gebrek aan insig in die dinamiek van meesternarratiewe en kontranarratiewe in die Skrif self - ' $n$ aspek wat later in die artikel verduidelik sal word.

\section{4. 'N HERVORMENDE SKRIFBESKOUING}

'n Middeweg tussen die twee radikale standpunte, naamlik om die Bybel summier te verwerp of om onkrities met die Bybel om te gaan, kom ook in die feministiese hermeneutiek voor. Hierdie benadering kan die 'hervormende Skrifbeskouing' genoem word. In hierdie siening word die patriargale agtergrond van die Joods-Christelike tradisie beskou as histories en nie teologies nie. Dit wil sê patriargalisme is deel van 'n vergange wêreld en is nie die norm vir mense se lewe voor God nie. Die tradisie van manlike dominansie en androsentriese diskriminasie word toegeskryf aan sosio-historiese faktore. Diskriminerende maatreels is aspekte wat kultureel bepaald is en is nie inherent aan menswees nie. Wanneer die praktyk aandui dat die kultuur nie meer in pas is nie, kan die maatreëls hervorm word. Die metode wat in so 'n betrokke hermeneutiek gevolg word, is onder andere om vroue-ervaring in die geskiedenis na te vors en om afgeskeepte bestaande bronne hieroor in publieke diskussie te bring. Verder word daar bewustelik gekies vir 'n 'hermeneutiek van suspisie'. Enersyds lees die eksegeet 'tussen die lyne' van die teks en andersyds lees die eksegeet selfs teen die grein van die teks in. In die eerste geval word die versweë positiewe rol van vroue in antieke bronne uitgelig. In die tweede geval word die chauvinisme wat daar in bronne kan wees, aan die kaak gestel as die invloed van die kulturele konteks.

Hoewel dit 'n 'hermeneutiek van suspisie' genoem kan word, is dit 'n benadering met 'n positiewe doelwit. Die tradisie (in die Bybel en in die kerk) word geag as die moeite werd om te rehabiliteer. Op 'n gematigde wyse word aangedui dat die situasie van androsentrisme en negatiewe ervaring van vroue nie langer gehandhaaf kan word nie en dat die post-moderne wêreld verandering noodsaaklik maak. Die bekende feministiese eksegeet, Phyllis Trible (1978, 1984, 1994; vgl ook Tavard 1973) is 'n eksponent van hierdie benadering. Die leemte van hierdie posisie is dat dit simptome dokter eerder as die siekcie.

\section{5. 'N ESTETIESE SKRIFBESKOUING}

Dit konfronteer nie die die verwronge aspekte in die sisteem direk nie. In hierdie benadering word die andersheid van vroulikheid beklemtoon. Daar word veral gelet op 
die wyse waarop vrouwees uitgebeeld word in simboliek, beelde en voorstellings in die kultuur. As die (A)nder funksioneer die vrou apart van die manlike wêreld. Wat vroulik is, is inherent superieur. Hier is geen strewe na gelykheid nie. Die hermeneutiek van hierdie benadering neem die vorm aan van die soeke na en estetisering van die ewig-vroulike in Bybelse simboliek. Voorbeelde van sulke simboliek is 'Israel as maagd', 'bruid van God', die 'kerk as die bruid van Christus', 'Maria as maagd' en 'moeder van Israel'. Wat hier gebeur, is dat die kerk in vroulike simboliek en die feminine mystique op estetiese wyse beklemtoon word. Hierdie benadering wat die klem lê op vroulike beelde vir God en Christus, geniet die afgelope tyd heelwat aandag (kyk Engelsman 1979; vgl ook Swidler 1979:21-73).

Die estetiese benadering reageer op die probleme van patriargalisme en androsentrisme deur nie self tot die stryd toe te tree nie. Die strategie is eerder om konflik met behulp van 'n 'simboliese idealisme' te bowe te kom. Egte vryheid word gesoek in die wêreld van simboliek. Dit gaan uit van die idee dat byvoorbeeld simboliese handelinge in onder andere die liturgie die gelowige kan help om die spanning van negatiewe ervaring in die werklikheid te oorkom. Mistiek, meditasie en kontemplasie speel ' $n$ belangrike rol. Die leemte van die benadering is die neiging tot isolasie uit die sosiopolitieke dimensie. Ook hierdie posisie konfronteer nie die sisteem direk nie. Dit is eerder geneig tot 'dogmatisme' wat vroulike en sosiale rolle op 'n abstrakte vlak plaas. Wanneer gedragsreels in die werklikheid as dogmas begin funksioneer, word dit ideologies swewend. Dogmas verloor hulle kontak met die grondvlak van die samelewing, word voorgehou as geldig oor tyd en plek heen en kan selfs 'ewigheidswaarde' verkry.

\section{6. 'N EMANSIPATORIESE SKRIFBESKOUING}

Een van die jongste benaderings tot die hermeneutiek van die Bybel is die beklemtoning van die bevrydingstema in die feministiese teologie. Dit is cok die benadering wat tans die meeste aandag in die feministiese hermeneutiek geniet (Osiek 1997:965; vgl Ackermann 1993:1-18). Die vertrekpunt van hierdie benadering is die bevrydingsteologie. In hierdie teologie staan die eskatologiese motief 'koninkryk van God' sentraal. Die taak en doel van gelowiges in die wêreld is om verlossing (bevryding) te bewerk. Dat hierdie verlossing ten volle verwerklik sal word, bied hoop vir die toekoms. Vir die vrou is die begin van hierdie gebeure die verwerkliking van bevryding van patriargale dominansie. Die doel van hierdie bevryding is dat alle mense vennote en gelykes kan wees en hulle taak gesamentlik kan verrig. Die onderdrukking van vroue word gesien as 'n aspek van 'n groter verskynsel, naamlik maghebbers wat domineer en mense aan hulle onderdanig maak. Dit is 'n proses wat sterk geinstitusionaliseer is en dit word gevind op die politieke, ekonomiese en sosiale terreine. Bekende eksponente is Elisabeth Schüssler Fiorenza (1985) en Rosemary Radford Ruether (1975, 1983). 
Schüssler Fiorenza, se strategie is byvoorbeeld om die vroee geskiedenis van die kerk te rekonstrueer. Haar doel is:

... [to] find ways to break the silence of the text and derive meaning from androcentic historiography and theology. Rather than understand the text as an adequate reflection of the reality about which it speaks, we must search for clues and allusions that indicate the reality about which the text is silent. Rather than take androcentric texts as informative 'data' and accurate 'reports', we must read their 'silences' as evidence and indication of that reality about which they do not speak. Rather than reject the argument from silence as a valid historical argument, we must learn to read the silence of androcentric texts in such a way that they can provide 'clues' to the egalitarian reality of the early Christian movement.

(Schüssler Fiorenza 1985:41)

Schüssler Fiorenza (1985:15) se feministiese hermeneutiek bestaan uit vier komponente, naamlik 'n hermeneutiek van 'suspicion', 'remembrance', 'proclamation' en 'creative actualization'. 'n Hermeneutiek van suspisie is volgens haar nodig omdat alle Bybeltekste ingebed is in patriargale kultuur, godsdiens en samelewing. Binne hierdie strukture is die Bybel gekanoniseer, geinterpreteer en verkondig deur mans (Schüssler Fiorenza 1985:53). Historiese rekonstruksie het ten doel om die versweë diskoerse van vroue uit die 'androsentriese teks' los te wikkel en om vroue te herintegreer as aktiewe deelnemers aan die geskiedenis waarvan hulle deel was (Schüssler Fiorenza 1985:54). Vir die doeleindes van die kerklike verkondiging moet ook die teologiese en etiese waarde van tekste geëvalueer word: '(T)exts which reinscribe patriarchal relations of domination and exploitation must not be affirmed and appropriated ... not be proclaimed as the word of G-d but must be exposed as the words of men' (Schüssler Fiorenza 1985:54). Met verbeelding en kreatiwiteit moet die swaarkry en oorwinnings van vroue 'opgebou' word uit die oorblyfsels in die tekste. Bybelse verhale word dan vertel vanuit ' $n$ ander perspektief en beklemtoon die bevrydende stemme wat stilgemaak is in die teks. Dit bou die rol van gemarginaliseerde figure uit en laat hulle stilte tot spreke kom (Schüssler Fiorenza 1985:54-55).

Hierdie strategieë help om die gekanoniseerde tekste en die vroeë geskiedenis van die kerk te dekonstrueer, maar ook om die vroeë kerk se geskiedenis te rekonstrueer as 'n inklusiewe geskiedenis van vroue én mans. Die ideologie-kritiek grondliggend aan die hermeneutiek van suspisie impliseer dus kritiese en dekonstruktiewe werk. Die her- 
meneutiek van herinnering wil rekonstrueer. Blote rekonstruksie sonder retoriese interpretasie berus volgens haar nie op kritiese werk nie. Haar visie kom voort uit wat sy die 'dissipelskap van gelykes' noem. Net dit in die Skrif wat tot die aktualisering van 'n 'gemeenskap van gelykes' bydra, behoort volgens verkondig te word. Haar hermeneutiese model is dus nie afhanklik van die rekonstruksie van historiese feite as sodanig nie. In 'n sekere sin tref sy 'n onderskeid tussen 'hermeneutiek' en 'retoriese interpretasie': 'Whereas hermeneutics seeks to explore and to appreciate the meaning of texts, rhetorical interpretation pays attention both to the kind of socio-symbolic worlds and moral universes biblical discourses produce, and to the way these discourses produce them' (Schüssler Fiorenza 1992:46). Schüssler Fiorenza is nie net in die betekenis van tekste in hulle historiese kontekste (rekonstruksie) geinteresseerd nie, maar ook in die identifisering van die stilgemaakte stem van gemarginaliseerdes sodat hierdie stem weer gehoor kan word. Haar retoriese kritiek se doelwit is om tekste 'n betekenis te laat gee wat 'n 'gemeenskap van gelykes' sal bevorder, 'n egalitêre struktuur met 'n epistemologiese raamwerk wat duidelik anders is as dié van die patriargale siste $m$. Sy beoefen haar eksegetiese werk met ander woorde in 'n ander paradigma as bloot die histories-kritiese of literatuur-teoretiese. Vanuit 'n monolitiese Skrifbeskouing kan die kritiek op die hermeneutiese uitgangspunte van Schüssler Fiorenza uitgeoefen word dat '... she has created a self-fulfilling interpretive circle where anything oppressive to women can be dismissed as patriarchal, and therefore not the Word of God' (Eriksson 1995:92).

Hoewel Schüssler Fiorenza die inklusiwiteit van vroue én mans in egalitêre relasies beklemtoon, funksioneer haar retoriese analise tog in 'n sekère sin eensydig. Vir haar is die ervaring van slegs vroue dié bron en dié norm van haar teologiese arbeid. Oor die gesag van die Bybel sê sy: '[The] Bible no longer functions as authoritative source but as a resource for women's struggle for liberation' (Schüssler Fiorenza 1985:14). Vir die verstaan van die teks het hierdie siening spesifieke gevolge volgens Schüssler Fiorenza (1985:13): 'A feminist critical interpretation of the Bible cannot take as its point of departure the normative authority of the biblical archetype but must begin with women's experience in their struggle for liberation'. Haar verstaan van die Bybel as 'prowtipe' in plaas van 'archetipe' hou voordele en nadele in. Die voordele van haar strategie is dat sy wel die aanvaarde histories-kritiese metode gebruik, terwyl haar appll tot 'historiese verbeelding' vroue bevry van die negatiewe formulerings in die teks. Met behulp van haar retoriese kritiek ontmasker sy die androsentriese vooroordeel van die teks en gee geboorte aan 'n nuwe visie van 'n egalitere gemeenskap wanneer die leierskapsrolle en volle deelname van vroue uit die tekste opgediep word. 
Buiten die gevaar van oorreaksie wat kan lei tot 'n volgende eensydigheid, is dit 'n dilemma om daardie 'egte' tradisie voordat die distorsies dit begin skeeftrek het, te probeer vind. Die poging om te ontsnap aan patriargale vooroordeel, bevry die rekonstruksie nie van eie vooroodeel nie. Byvoorbeeld, teenoor die redenasie eeue lank gehoor dat vroue nie georden kan word nie omdat die dissipels van Jesus almal manlik sou gewees het, toon Schüssler Fiorenza se leesstrategie aan dat daar onder Jesus se dissipels wel vroue was en dat hulle teenwoordigheid deur androsentrisme verswyg is. Haar eksegetiese resultaat is dus 'n verdediging van die teenoorstaande standpunt, maar dit ontmasker die eensydigheid in die redenasie nie as 'n valse uitgangspunt nie. Verder bied haar leesstrategie om tekste te dekonstrueer nie 'n oplossing vir diegene in die geloofsgemeenskap wat verkies om nie agter die teks te werk nie, maar wel met die teks soos dit voor die leser lê (kyk Tolbert 1990:11-12). Bowendien bly dit 'n kritiese vraag of vroue-ervaring as die eensydige norm vir wat geldig is en wat nie, 'n beter toegang tot inklusiwiteit verleen. Haar visie kan gesien word as wensdenkery - die vertrekpunt word nie gevind in die geskiedenis en die teenswoordige realiteit nie (Eriksson 1994:98, 104).

Ook vir Rosemary Radford Ruether $(1983: 12,18)$ is ervaring as sodanig en vroueervaring in die besonder baie belangrik. Vir Ruether (1983:18) is dit nie ervaring wat dié norm is vir haar teologiebeoefening nie, maar wel die beginsel: 'the promotion of the full humanity of women'. Hierdie beginsel vind sy 'tussen die lyne' van die tradisie en beskou dit as normatief. In 'n Christelike konteks beteken dit die bedoeling en die 'wil van God'. Hoewel Ruether vroue-ervaring nie normatief wil maak vir die beoefening van teologie nie, wys Eriksson (1994:111, 113-114) tog krities uit dat sy vroue se ervaring wel beskou as nader aan die waarheid, aangesien die marginale posisie wat vroue beklee, minder geleentheid bied tot distorsies. Dit lei daartoe dat wat manlik is, tog vervang moet word met die vroulike wat op 'n manier 'beter' is. Ruether pleit nie vir 'n byvoeging van vroue se ervaring tot dié van mans om die eensydigheid van die geskiedenis uit te skakel nie. Ook hier word die een eensydigheid vervang met ' $n$ ander.

Volgens die emansipatoriese hermeneutiek is die bevryding van die mens die sentrale boodskap van die Bybel. Verlossing beteken om vrygemaak te wees. Dit is 'n benadering wat daarop klem lê dat geen interpretasie van die Bybel objektief en waardevry geskied nie. Hierdie hermeneutiek erken openlik dat die vertrekpunt in eksegese vanuit spesifieke vooronderstellings geskied en daarom moet die spesifieke saak van bevryding nie in die eksegetiese proses ontken word nie. Rosemary Ruether (1983) meen dat die sentrale boodskap van die Bybel in die profetiese tradisie gevind word. Die profetiese tradisie verkondig die bekering van 'n onregverdige sosiale bestel. Dit 
roep die volk Israel op om 'n samelewing te vestig wat vry is van onderdrukking. Hoewel die profetiese tradisie nie op vroue gerig is nie en selfs in 'n patriargale konteks ingebed is, meen Ruether dat die profeteboodskap bevrydend vir alle mense is. Hierdie boodskap moet net van die historiese en kulturele konteks bevry word. Elisabeth Schüssler Fiorenza (1985) werk spesifiek met Nuwe-Testamentiese tekste wat androsentriese en patriargale strukture corstyg en 'n visie op 'n verloste mensheid bied. Sy wil nie net die betrokke tekste binne hulle patriargale raamwerk herinterpreteer nie, maar wil dit benader vanuit die perspektief van verlossing en 'n nuwe skepping. So 'n visie het nie net die interpretasie van die Bybel ten doel nie, maar loop ook uit op 'n transformasie van die breè sosiale orde. Hiervolgens verwerp die emansipatoriese hermeneutiek nie die tradisie nie, maar eis ' $n$ totale herstrukturering daarvan.

Hierdie hermeneutiese beginsel is besonder spesifiek. Wat ook al afbreuk doen aan die volle mensheid van vroue, is nie 'n weerspieëling van 'n egte lewe voor God nie. So 'n verwronge kommunikasie bevat nie die boodskap van egte verlossing nie. Wat wel die volle mensheid van vroue bevorder, is van God en weerspieel 'n egte verhouding met God. Simmetrie is die outentieke boodskap van verlossing en dit is die taak van gelowiges wat verlossing ervaar om die boodskap verder te dra (Ruether 1983:19). Die Skrifbeskouing in hierdie benadering gaan dus ook uit van die teenwoordigheid van meesternarratiewe en kontranarratiewe in die Bybel (vgl Breytenbach 1997). Die emansipatoriese hermeneutiek beskou alleen daardie tekste en eksegetiese modelle wat hulle patriargale kontekste krities oorstyg en ruimte gemaak het vir 'n subjeksubjekverhouding as die egte 'openbaring'. Volgens Schüssler Fiorenza (1985:30) is die Bybel God se openbaring daar waar 'n visie van Christelike vroue as subjekte in sowel die geskiedenis as in die teologie figureer.

Daar kan geredeneer word dat die swakheid van die emansipatoriese hermeneutiek lê in die beperkte siening van die konsep 'openbaring'. 'Openbaring' word op 'n simplistiese wyse gelyk gestel aan 'gesag'. Alles wat nie aan die gestelde kriterium konformeer nie, word verwerp as 'nie-openbaring'. Die kriterium lê nie in die eerste plek by 'n Gods-gebeure nie, maar in die vroue-ervaring. Dit lyk asof die profete, Jesus en soms ook Paulus op 'n reduksionistiese wyse verhef word as 'n 'kanon-in-die-kanon' (Osiek 1997:966). Die latere skrywers van die Nuwe Testament wat reeds ingebed geraak het in die institusionalisering van die vroeg-katolisisme, word verwerp omdat hulle nie aan die bevrydingskriterium voldoen nie.

\section{DIE SKRIF VANUIT DIE PERSPEKTIEF VAN 'N EPISTEMOLOGIE VAN DEELNAME}

Die hedendaagse beklemtoning van pluraliteit in die samelewing hou direk verband met die bewussyn van Bybelwetenskaplikes vandag dat daar in die Skrif meerdere tradisies 
wat selfs teensprekend van aard is, aanwesig kan wees. Hierdie insig in die Bybelwetenskap is die regstreekse gevolg van die histories-kritiese benadering in die eksegese. Die historiese kritiek het nie net die aanwesigheid van verskillende tradisies en die redaksionele verwerking daarvan geidentifiseer nie. Dit het ook die verskillende Sitze im Leben (sosiale kontekste) waarbinne hierdie tradisies en redaksionele aktiwiteit plaasgevind het, uitgewys. Hierbenewens het die historiese kritiek skerp ondersoek ingestel na die vroegste bedding van waanit tradisies kon ontspring het. Een van die belangrike bydraes van die historiese kritiek is dat die eksegeet, vanweë die kompleksiteit van sowel die Bybel as die samelewing, nie meer op 'n naïewe fundamentalistiese wyse met die Bybel kan omgaan nie.

Die aanvulling. van die histories-kritiese metodes met aspekte van onder andere die narratologie en die sosiaal-wetenskaplike kritiek, het 'n verskuiwing in die hermeneutiese gerigtheid teweeggebring (kyk Vorster 1988:31). Die gevolg was dat die klem in eksegese nie net meer gelê het op die historiese verstaan van tekste nie, maar ook op die resepsie daarvan. Binne hierdie nuwe raamwerk waar die pragmatiek van tekste 'n plek gekry het, stel Van Aarde (1994) 'n hermeneutiese benadering voor wat hy die betrokke hermeneutiek noem. Deur middel van betrokke hermeneutiek funksioneer die gesag van die Bybel vir die gelowige in 'n proses van ontmoeting met die 'verhale' in die Bybel. Die Bybellesers raak bewustelik betrokke by wat hulle lees en die waardes wat hulle so ontmoet, bring hulle tot selfkritiek. Hierdie proses lei daartoe dat die lesers van die Bybel die waardes wat daarin betuig word, hulle eie maak of dit verwerp. Dit kan beskryf word as 'n 'epistemologie van deelname'. Hier is nie sprake van 'n asimmetriese ontmoeting, asof die mens besluit wat aanvaarbaar is of nie. Dit is nog steeds die waardes in die Bybel wat 'n appèl tot die mens rig. 'n Skrifbeskouing wat aan die mens ruimte vir betrokkenheid verleen, geskied binne 'n epistemologie van deelname. Dit is 'n ontmoetingsproses, 'n horisonversmelting. Hierdie proses sluit aan by die kommunikatiewe handelingsteorie van Jürgen Habermas, in die besonder sy teorie van die 'ideale gespreksituasie' waarbinne simmetries kommunikatiewe handelinge geskied.

\section{DIE KOMMUNIKATIEWE HANDELINGSTEORIE}

\subsection{Die kritiek op die hermeneutiese benadering}

In die teologie word Jürgen Habermas ([1981] 1984) se teorie van die 'ideale gespreksituasie' waarbinne simmetries kommunikatiewe handelinge geskied, toenemend aanvaar as 'n bruikbare metateoretiese uitgangspunt. In Habermas se kommunikatiewe 
handelingsteorie word daar uitgegaan van die siening dat die menslike samelewing 'n netwerk van kommunikatiewe handelingspatrone is. In hierdie gerigtheid het wetenskaplike kennis nie meer net betrekking op die objektiewe werklikheid van dinge en gebeurtenisse nie, maar ook op die sosiale werklikheid van geldende waardes en norme, en die subjektiewe werklikheid van intensies, behoeftes en gevoelens.

Die kritiese teorie is die oorkoepelende begrip waaronder die kommunikatiewe taalhandelingsteorie val en dit hoort tot die sogenaamde Frankfurter Schule. Benewens Habermas, is filosowe soos Theodor Adorno en Herbert Marcuse belangrike eksponente van die Frankfurter Schule. Wat dikwels in die teologie uit die oog verloor word in die nadenke oor metateorie, is dat die kritiese teorie bedoel is as 'n alternatief en korrektief op die tradisionele hermeneutiese benadering. Die konsensusprinsiep (versmelting van horisonne) word nie meer onkrities aanvaar nie (kyk Klemm 1986a:203208). Die hermeneutiese benadering gaan uit van die aanname dat daar 'n 'horisonversmelting' plaasvind in die kommunikatiewe handelingsproses tussen subjek en objek en dat daar tegelykertyd 'n rolleverwisseling plaasvind. Objek word subjek. 'n Illustrasie van die probleem is dat, indien die objek byvoorbeeld vanweë sisteemrelasies pyn geïnternaliseer het, 'n rolleverwisseling nie vanself sal meebring dat die ervaring van pyn herken en as 'n probleem geïdentifiseer word nie. Inteendeel, juis omdat die objek wat die draer van pyn is nou die status van subjek kry, word die moontlikheid tot herkenning nog verder versluier.

'n Voorbeeld daarvan dat die problematiek rondom die begrip 'rolleverwisseling' in die hermeneutiese benadering nie altyd raakgesien word nie, kan in die werk, van Karl Barth aangetoon word. Barth is bekend daarvoor dat hy ' $n$ besonder dinamiese Skrifbeskouing gehad het. Vir hom was die Bybel nie in die direkte sin van die woord gelyk aan God se Openbaring nie: 'Die Bibel ist ... nicht selbst und an sich Gottes geschehene Offenbarung' (Barth [1932] 1964:114). Die Bybel is vir Barth 'das konkrete Mittel, durch das die Kirche an Gottes geschehene Offenbarung erinnert, zur Erwartung künftigen Offenbarung aufgerufen und eben damit zur Verkündigung aufgefordert, ermächtigt und angeleitet wird' (Barth 1964:114; my beklemtoning). Otto Weber (1967:16) wys daarop dat die Bybel vir Barth eers dan Openbaring word 'wo das Bibelwort als Zeugenwort in Funktion tritt' (kyk Barth 1964:116).

Die probleem is egter geleê in die moontlikheid dat hierdie dinamiese Skrifbeskouing ontkragtig kan word, indien dit nie eksistensieel grondraak nie. Daarom moet die opmerking wat H Zahrnt in sy boek Die Sache mit Gott gemaak het, ter harte geneem word (vgl ook Pieterse 1979:28). Zahmt ([1966] 1967:141) het Barth se teologie gekritiseer omdat dit dikwels corkom as 'n 'Monolog im Himmel'. Dit lyk of dit toegeskryf kan word aan die feit dat die rolleverwisseling 'subjek-objek' nie by Barth neer- 
kom op 'n subjek-subjek verhouding nie, maar steeds in omgekeerde sin van die woord 'n subjek-objek verhouding. Pelser (1992:20) beskryf Barth se siening hieroor soos volg: 'In 'n debat met A Harnack, wat steeds die natuurwetenskaplike subjek-objek skema ook vir die Skrifuitleg voorgestaan het, stel Barth dat onthou moet word dat die Bybelse teks as objek eers (en eerste) subjek was, en altyd weer subjek moet word. Dit is dus die objek wat nou as subjek, vrae aan die subjek, nou die objek, stel.' Resloos kan Barth (1960:760) daarom van die 'Freiheit des Wortes' praat, sonder 'n bewuswording dat wanneer die kerk God se Woord in 'n woordgebeure kommunikeer, bestaande verwronge kommunikasie in die Skrif as normatief oorgedra kan word. Omdat God se Woord (die subjek) 'n 'vryheid' het wat nie deur die mens (die objek) aan bande gelê kan word nie, praat Barth in terme van 'mag' as hy na die 'gesag' van die Skrif verwys:

\begin{abstract}
Die Freiheit des Wortes besteht entscheidend in der 'Macht', die uns in der Heiligen Schrift gegenübertritt und 'die grundsätzliche Problematisierung aller anderen Subjekte' in der Welt darstellt. Ja, 'die ganze Wahrheit ist daB die Heilige Schrift in ihrer ganzen Unscheinbarkeit mehr Macht hat als die ganze übrige Welt zusammen'.
\end{abstract}

(Barth, in Weber 1967:47)

Rudolf Bultmann ontkom met sy eksistensiale hermeneutiek die kritiek van 'n 'Monolog im Himmel'. Sy hermeneutiese benadering maak baie meer as Barth erns met die moderne mens se lewensituasie. Tog gaan ook hy, vanuit 'n ideologies-kritiese hoek gesien, nie ver genoeg nie. 'Bultmann's individualism, however, is well known. The apparent lack of explicit social and political awareness, either in Bultmann's New Testament work or in that of the post-Bultmanians who sought Jesus by an existential route, has proved costly' (Marsh 1997:415).

Die insig in die feit dat kommunikasie deur die soeke na eie magsbelange verwring kan word, het eers in die na-Aufflarung era aangebreek. Die verdiskontering van hierdie insig is voorwaarde om werklik van 'n kommunikasie op 'n subjek-subjek as te praat. Iets van die deurbreek van hierdie insig in die hermeneutiese benadering kan wel by Hans-Georg Gadamer gesien word. Wanneer Gadamer (1994:311), die pionier van die nuwe hermeneutiese benadering, die hermeneutiese sirkelkonsep (dws die konsep 'rolleverwisseling') op die interaksie met die Bybel toepas, sien hy in dat onderwerping aan die Bybel nie ' $\mathrm{n}$ kwessie van dominansie van die kant van die Bybel moet word nie, maar eerder 'n saak van om te dien. Indien hierdie aspek van om te dien nie eksplisiet 
in die hermeneutiek in ag geneem word nie, kan die hermeneutiese benadering opgaan in 'konvensionalisme' omdat die gesag van die teks onbevraagtekend aanvaar word. Om in te sien dat daar in die leefwereld van die Bybel nie altyd gedien was nie maar geheers (kyk Mark 10:42-44), is ideologiekritiek, toegepas ook op die Bybel, noodsaaklik.

Habermas (kyk Maddox 1985:524; vgl Vos 1996a:19) is nie ondialekties in sy taalhandelingteorie nie, maar is krities ingestel op tradisionele dialektiek wat voortgaan om pyn as probleemloos in die kommunikatiewe handeling te aanvaar. Daarom staan sy kommunikatiewe talhandelingteorie bekend as ' $n$ (self)kritiese dialektiese teorie. Hierdie teorie is dus krities ingestel op dialektiek terwyl dit terselfdertyd vanuit dialektiese denke opereer. Hy gaan nog steeds uit van die kommunikatiewe as. Dit wil sê die objek in die kommunikatiewe handelingsproses word nie net vir hom subjek as gevolg van 'n rolleverwisseling nie, maar twee ander sake wat nie deur die tradisionele hermeneutiese benadering in ag geneem word nie, is vir hom ook belangrik. Dit is naamlik dat die subjek in die kommunikatiewe handelingsproses nie omgekeer word in 'n objek vanweè die rolleverwisseling nie, maar subjek bly, sodat die kommunikatiewe handelingsproses dié is van die ontmoeting van subjek met subjek. Verder is hy krities ingestel daarop om wat die objek in die cerste plek tot objek gemaak het en watter pyn objektivisering veroorsaak het, na die oppervlak te bring in die proses van kommunikasie. So 'n kenaksie is derhalwe ingestel op simmetrie. Die kommunikatiewe handelingsproses wat ingestel is op simmetrie (subjek-subjek) wil in die kenaksie pyn as probleem identifiseer.

\subsection{Kennis en belange}

Habermas noem die kenaksie wat ingestel is op simmetrie die 'emansipatoriese kognitiewe belang' en dit geskied in terme van die 'ideale gespreksituasie' (kyk Snyman 1987; Klemm 1986a; Peukert 1989). In hierdie verband onderskei hy tussen drie tipe 'belange' wat in kommunikasie, dit wil sê in die ontmoeting van mens met mens en dinge, aanwesig kan wees. Kennis is nooit belangevry nie, ook nie die verwerwing van kennis nie en ook nie die kenaksie (kommunikasie) nie. Dit is omdat kennis nie 'n 'suiwer' weerspiezling van die werklikheid is soos daar in die positivisme gemeen word nie. Die drie tipe 'belange' wat onderskei word, is die 'tegniese' belang, die 'praktiese' (ook genoem die 'pragmatiese' belang) en die 'emansipatoriese kognitiewe' belang. Laasgenoemde beskryf hy as die kompetensie tot simmetriese kommunikasie.

Die tegniese (praktiese) belang beoog om natuurlike en sosiale gebeure te voorspel om sodoende te kan manipuleer. Dit gebeur in 'n verfynde positivistiese sisteem wat 
nie afstand kon doen van die kousaliteitsbeginsel nie. Later sal ek aantoon hoe die verband tussen oorsaak en gevolg die uitwerking het dat die ou natuurwetenskaplike visie in die modernistiese paradigma wetmatighede aanvaar. Die beginsel van wetmatigheid is inherent deel aan die oorname van die ou natuurwetenskaplike visie van die modernistiese paradigma op die terrein van sosiale gedrag. Sogenaamde wetmatige natuurprosesse wat as onveranderlik beskou word, word op 'n ongeldige wyse toegepas op die prosesse van die interaksie tussen mense asof hierdie prosesse mense vasvang in onveranderlike kontoere. Dit het byvoorbeeld die uitwerking dat die pyn wat mense ervaar vanweë sekere vasgelegde gedragspatrone maar net aanvaar moet word, nie as 'n probleem geidentifiseer word en derhalwe nie ter wille van restourasie verander word nie. Die tegniese (praktiese) belang beoog volgens Habermas om die (A)nder (die tradisionele objek in die kommunikatiewe as, voordat objek as subjek erken is) te verstaan om sodoende met haar of hom te kommunikeer. Hierdie $(A) n d e r$ is ' $n$ begrip ontleen aan post-moderne denkers soos Emmanuel Levinas (kyk Donoghue 1996:37-47) en Michél Foucault (kyk Beukes 1996:233-251). Die strekking van die klem op die (A)nder is gebore uit deernis vir mense wat tot nie-identiteit verword het as gevolg van die toedoen van ander in die posisie van mag. Wanneer die ander in interaksie met jouself jou selfstandigheid op die een of ander manier respekteer, kan daar in hierdie interaksie betekenis tot stand kom. Singewing in interaksie bestaan egter alleen wanneer nieidentiteit opgehef word met identiteit. Nie-identiteit is om 'n ander sonder 'n hoofletter te wees. Identiteit is om $(A)$ nder te wees.

In die post-moderne diskoers van Michél Foucault (kyk Beukes 1996:71) lê die klem nie as sodanig op verstaan nie, maar op ervaring. Hierdie studie gaan nie in op die filosofiese debat tussen Habermas en die post-moderne filosowe nie (kyk De Pater 1996:177-202). Tog is die bydrae van post-moderne denkers ten opsigte hiervan belangrik. Hulle herken dit as 'n probleem in kommunikasie wanneer 'objekte' vanweê objektivering tot nie-identiteit vervlak word en dit as pynlik ervaar.

Habermas se kritiese teorie het as doelstelling die derde tipe belang, naamlik die emansipatoriese kognitiewe belang. Hierdie 'belang' wil 'n samelewing vry van verwronge kommunikasie bevorder en aanmoedig. Die woorde 'bevorder' en 'aanmoedig' is hier belangrik. Soms word Habermas gekritiseer dat sy teorie op 'n utopie neerkom, omdat in hierdie gebroke wêreld daar nooit 'n toestand van 'n ideale egalitariteit bereik kan word nie (kyk Snyman 1987:173; Romm 1987:195). Die kritiese teorie is in hierdie opsig anders as die klassieke Marxisme. Dit het juis ontstaan binne die neo-Marxistiese skool wat kritiek uitoefen op Marx se idee van 'n klasselose samelewing. Die kritiese teorie wil wel die ideaal van nie-manipulasie en uitbuiting bevorder en aanmoedig. Mense word deur middel van hierdie kritiese teorie bewus gemaak dat die ideaal nie 
verwesenlik is nie. Daarom roep die kritiese teorie mense op om deurentyd, in alle samelewings, krities ingestel te wees op manipulasie en uitbuiting. Hierdie standpunt sluit teologies aan by 'n perspektief van iemand soos byvoorbeeld Paulus. Paulus gaan altyd uit van die indikatief van die heil en roep gelowiges op om te word wat hulle reeds is. Daarom is daar altyd 'n imperatief omdat, hoewel die heil verkondig word, dit in hierdie gebroke wêreld net vir die geloofsoog sigbaar is.

\subsection{Verfynde positivisme}

Uit die bespreking sover het dit geblyk dat die kommunikatiewe handelingsteorie wat simmetrie in die $\infty \mathrm{g}$ het, die tradisionele hermeneutiese benadering verfyn. Dit het ook duidelik geword dat daar nie van dialektiek afstand gedoen behoort te word nie. Indien daar in die metateorie nie 'n daadwerklike verskuiwing plaasvind vanaf die subjek-objek as tot die subjek-subjek as nie, het ons hier te doen met 'n verfynde positivisme. Met ander woorde die dialektiese teologie kan dus maklik die slagoffer word van juis die ding waarvan dit wou afstand doen. Daarom is dit belangrik om daarop te let dat positivisme deur drie verskillende ontwikkelingsfases gegaan het (vgl Mouton 1987:1-29).

Die eerste fase is opgevolg deur die negentiende-eeuse positivisme wat weer opgevolg is deur die twintigste-eeuse logiese positivisme. Francis Bacon het die belangrikste invloed uitgeoefen gedurende die eerste periode. Sy vertrekpunt in wetenskaplike ondersoek is om empiriese data daar te stel. Daarna toets hy die geldigheid van enige teorie of hipotese ook aan empiriese data. Met ander woorde, so 'n benadering kom neer op wat genoem word 'deduktiewe argumentvoering'. Dit is 'n manier van redevoering wat neerkom op 'n proses van afleiding (deduksie) vanuit 'n vaste, empiriesbepaalde vooringenome posisie van wat geldig geag word. Wetenskaplike ondersoek begin dus nie by die postulering van 'n hipotese voor die aanvang van die kenaktiwiteit nie. Hierdie kenteorie, by wyse van empiriese waarneming en toetsing, is in die besonder bevorder en ontwikkel deur geleerdes soos Thomas Hobbes (1588-1679), John Locke (1632-1704) en David Hume (1711-1776). Hobbes, byvoorbeeld, definieer die konsep 'kousaliteit' in die wetenskapsteorie as 'n aangeleentheid wat empiries waargeneem word deurdat dit bestaan uit die relasie van gegewens of gebeure.

So 'n teorie van sogenaamde 'ware kennis' het in die verlede as onderbou gedien vir 'n idealistiese mensbeskouing omdat mense begin glo het dat die mensheid progressief vooruitgaan. Met die $\infty \mathrm{g}$ op die kerklike praktyk is dit belangrik om te herken dat so 'n positivistiese sisteembeskouing nie in staat is om, vanweë 'n inherente idealistiese mensbeskouing, die pyn wat in die sisteem kan beleef, na die oppervlak te bring nie. 
Hierdie beskouing bevestig die opinie dat daar tog nie in 'n sogenaamde 'goeie' samelewing, bestaande uit 'progressiewe' vooraanstaande mense, pyn veroorsaak kan word aan ander vrout nie. Gedurende die tweede periode, die negentiende-eeuse positivisme, het die denke van geleerdes soos Henri Saint-Simon (1760-1825), Auguste Comte (1798-1857) en Emile Durkheim (1858-1917) die toneel oorheers. Op die terrein van die sosiologie het Durkheim bekend geword vir sy beklemtoning van die sogenaamde objektiewe en feitlike aard van sosiale gegewens. Enige sosiaal-wetenskaplike ondersoek wat die gevaar wat hierin opgesluit is, nie insien en uiters selfkrities met die beskrywing van menslike interaksie omgaan nie, kan maklik in so 'n positivisme verval. Dit laat nie die moontlikheid oop dat iemand binne die stelsel anders kan wees, dink en handel nie. Saint-Simon was oortuig daarvan dat wetenskap alleen 'n positiewe bydrae kan maak as dit geldige aansprake voortbring wat getoets is deur empiriese gegewenhede. Sy vertrekpunt is dus nie meer 'n vaste, empiries waargenome basis nie. Sy fokus is eerder die eindresultaat wat egter wel deur empiriese data geverifieer moet word.

Geleerdes het toenemend begin bewus raak van die verskil tussen die natuurwetenskap en die geesteswetenskappe. Later beskryf Wilhelm Dilthey die natuurwetenskaplike proses as verklaring waarteenoor hy die geesteswetenskaplike proses sien as interpretasie. Thiselton $(1980: 235)$ tipeer Dilthey se bydrae in hierdie verband soos volg:

Wilhelm Dilthey (1833-1911) saw that historical understanding is not a matter of 'explanation' in terms of general laws which are relevant to the sciences. The methods and laws of the Naturwissenschaften are to be distinguished from those of the Geisteswissenschafien. The latter concern the particularities of human life (das Leben) and understanding (Verstehen) ... Life, for Dilthey, included man's thinking, feeling, and willing ....

Wat die negentiende-eeuse positivisme betref, is vaste wetmatighede ook vir Comte nou nie meer die vertrekpunt nie. Na die ondersoek toets hy egter wel die resultate aan empiries-waargenome data. Met ander woorde, hy doen nie afstand van die kousaliteitsbeginsel nie. Sy benadering kom daarop neer dat wetmatighede byvoorbeeld ook op die terrein van sosiale interaksie geidentifiseer kan word. Streng gesproke kom dit daarop neer dat van mense 'masjiene' gemaak word. Hierdie geskepte 'wetmatigheid' in die geesteswetenskap sal volgens hierdie benadering 'n algemene aanvaarbaarheid hê 
omdat dit 'n onveranderlike en konstante ooreenkoms van waargenome werklikhede beskryf. Die geloofwaardigheid van verskynsels wat nie opsigtelik in wetmatige patrone voorkom nie, word alleen as geloofwaardig erken wanneer hulle beskou word as besondere gevalle van universele beginsels. Die implikasie is dat alles wat anders is, volgens hierdie houding nie bestaansreg het nie. Met betrekking tot die kerklike praktyk bestaan daar in hierdie positivistiese benadering dieselfde gevaar as wat hierbo uitgewys is. Enige denkstruktuur wat onkrities met die begrip 'wetmatigheid' omgaan, loop die gevaar om die besondere aard van mense se ervaring te ontken en nie daardie strukture wat ervaring negatief beinvloed, te identifiseer en in ander bane te stuur nie.

Die derde periode, die twintigste-eeuse logiese positivisme, word veral gekenmerk deur die dominansie van die Weense Kring ('Wiener Kreis'). Gedurende hierdie periode is die sogenaamde 'objektiwiteitsbeginsel' wat strak data verifieer, oorstyg. In die plek van die objektiwiteitsideaal het 'n 'induktiewe' argumentvoering gekom. Die empiriese kenaktiwiteit word reeds voor die aktiwiteit self deur 'n gekose vertrekpunt in ' $n$ bepaalde rigting gestuur. 'n Gekonstrueerde model of basis vorm hierdie vertrekpunt. Die resultaat is reeds vooraf bepaal, ongeag wat daar ook al oor die praktyk waarbinne ' $n$ objek hom of haar bevind, aan die lig kom.

Teenoor alle positivistiese benaderings kom die hermeneutiese benadering, soos dié van Wilhelm Dilthey, Hans-Georg Gadamer en Paul Ricoeur, as 'n radikale alternatief (vgl Vos 1996a:23-25, 29-30). Thomas Kuhn se teorie van paradigmaskuiwe is eweneens 'n alternatief op die positivisme. Die kommunikatiewe handelingsteorie wys die gevaar uit van 'n verskuilde positivisme in die hermeneutiese benadering, maar gaan wel uit van dialektiese denke in die kritiese bevordering van die ideale gespreksituasie.

\section{DIE BEWUSWORDINGSPROSES}

Wanneer die kritiese teorie toegepas word op die feministiese hermeneutiek sal die positivisme wat.verskuil lê in 'n onbevraagtekende hermeneutiese oriëntasie egter nie net daar gelaat kan word nie. 'n Onkritiese beskouing oor wat as 'norme' geld (gebore binne 'n onaanvaarbare objektiwiteitsideaal) en 'n beskouing oor onveranderlike gedragspatrone (gebore in 'n onaanvaarbare kousaliteitsbeginsel) sal nie gehandhaaf kan word nie. Die kommunikatiewe handelingsteorie staan ' $n$ aktiewe betrokkenheid by die geskiedenis voor. Dit aanvaar nie dat mense net aan die geskiedenis, wetmatighede en gedragspatrone uitgelewer is nie. As teorie word dit self gesien as 'gefalsifiseer': die pragmatiese, morele ideaal dat mense hulle eie sosiale omstandighede verstaan en op grond van hierdie selfbewussyn die omstandighede self begin verander, word 'n werklikheid. Die kommunikasie-as is dié van subjek-subjek. Hier is geensins sprake van 'n slagoffersindroom nie. Bewuswording by alle partye is die middel tot die doel om simmetrie in kommunikasie te bevorder. 
Volgens Habermas ([1970] 1981:233) verhinder verskeie dinge egter die voltrekking van die ideale gespreksituasie waarin volledige simmetriese kommunikasie kan geskied. Tipies aan die dialektiese denke binnc die hermeneutiese benadering, beklemtoon Habermas (kyk Romm 1987:192) voortdurend die verband tussen samelewing en individu. Hiermee word bedoel dat die samelewing gekonstitueer word deur gesosialiseerde individue. Wat die individu is, is alleen deur integrasie binne 'n sosiale proses, en wat die samelewing is, word slegs 'n werklikheid deur middel van die interaksie van die individue wat met die samelewing geintegreerd lewe. Wat die saak verder kompliseer, is dat die samelewing as sosiale proses 'n geskiedenis en ook 'n georganiseerde opset het. Die organisasie van die samelewing is die samelewing se 'rasionaliteit'.

Met 'rasionaliteit' word bedoel dat daar in die samelewing 'n beskrywing en verklaring gebied word van die bepaalde georganiseerdheid daarvan. Die daad van 'rasionalisering' veronderstel die een of ander vorm van mag ter wille van die een of ander gesamentlike doel met die oog op die verwerwing van kennis. Die ironie is egter dat 'rasionaliteit' in hierdie proses nie as 'rasioneel' ervaar word nie. Vanuit byvoorbeeld die Marxisțiese perspektief mag die rasionaliteit van produksieprosesse, dit wil sê die beskrywing en verduideliking van produksie, wel vir die rede begrypbaar wees, maar dit is irrasioneel deurdat dit nie bewus is van die vernietiging van mense se vryheid en die lyding wat dit meebring nie. Met vernietiging van vryheid word bedoel dat produksieprosesse mense as 'masjiene' in arbeidskofte giet. Die pyn wat hier ter sprake is, is dat mense vervreemding beleef, omdat onderwerping aan produksieprosesse en die mag wat hierdie prosesse as goed en korrek beskryf, hulle die vryheid van outentieke' bestaan ontneem. Vervreemding van sigself kom daarop neer dat eie ervaring onderdruk word. Selfvervulling veronderstel dat identiteitloosheid opgehef word. Mense wie se ervaring genegeer word, word tot nie-identiteit verviak. Selfvervulling (personale Identität) kan alleen binne simmetriese relasies in 'n samelewing geskied. Francis Fiorenza (1989:125) stel dit met betrekking tot Habermas se kommunikatiewe handelingsteorie soos volg:

... eine Korrespondenz besteht zwischen der personalen Identität und der Identität einer Gemeinschaft. Personale Identität entwickelt zich intersubjectiv [subjek-subjek] in Beziehung zur Reziprocität zwischen der Identifizierung durch andere Subjecten und der Ich-Identität sowie zwischen den Strukturen der Gruppe und der Ich-Identität. Folglich existiert eine Interdependenz zwischen Normensystemen und den Strukturen der Ich-Identität. 
Met ander woorde, wanneer normsisteme in 'n samelewing op 'n dominerende kommunikatiewe wyse funksioneer, is self-vervulling nie moontlik nie. Veral vroue is maklik deur hierdie prosesse tot slagoffers gedoem vanweē die feit dat die rasionalisering waarvan hier gepraat is, vanuit manlike dominansie geskied. 'n Pleidooi vir 'n normsisteem sonder dominansie van 'n maghebber veronderstel nie 'n ideaal van 'n samelewing sonder norme nie. Daar is egter ook iets soos skeefgetrekte norme.

Die kritiese teorie, waar onder andere Habermas (vgl Snyman 1987:155-177) se kommunikatiewe handelingsteorie val, wil 'n verandering van ervaring teweeg bring sodat daardie ervaring wat voortspruit uit versluierde probleme in die samelewing, aan die lig kan kom. Die kritiese teorie is daarom geinteresseerd in 'n rasionaliteit wat fokus op hoe die samelewing sigself organiseer ten opsigte van die nood wat in die samelewing ervaar word. Die teorie wys uit dat die spanning in die samelewing nie klop met die samelewing se idee van die ideaal nie. Die kritiese teorie verteenwoordig 'n kritiese denke wat begrip toon vir die mens. Hierdie begrip is in stryd met die ideaal wat die samelewing meen tog in die samelewing aanwesig is. Omdat die samelewing van sigself die goeie verwag, bestaan daar nie altyd 'n bewuste insig in die dinge wat hierdie ideal verwring nie. Die kritiese teorie bevorder bewuswording.

Theodor Adorno het hierdie kritiese denke by geleentheid 'immanente kritiek' genoem (kyk Snyman 1987:170). Hy bedoel daarmee dat dit nie net gerig is op daardie diskrepansie tussen wat die samelewing meen dit idealisties verteenwoordig en wat dit in werklikheid is nie, maar eerder op 'n konfrontasie met hierdie valse begrip wat die samelewing van sigself het. Die toename in tegniese middele om die natuur te beheers mag weliswaar ' $n$ toename in welvaart beteken het, maar het geskied ten koste van die kreatiwiteit van mense in hulle arbeidsituasie, in hulle denke, en in hulle ervaring. Vooruitgang, indien dit ook nie in kritiese lig gesien word nie, lei maklik tot die verdingliking van die mens. Indien 'n manlik gedomineerde rasionalisering van wat goed en reg is, nie in 'n kritiese lig gesien word nie, word vroue skade berokken omdat hulle negatiewe ervaring ten spyte van voorspoed nie raakgesien word nie. Die rasionaliteit van 'n samelewing is dus irrasioneel: dit maak tegniese vooruitgang moontlik, maar kan daartoe lei dat outentieke lewe vir mense verhinder word.

Negatiewe ervaring bring mee dat daar in die wetenskapsteorie ruimte gemaak word vir 'n kritiese teorie. Die inhoud van negatiewe ervaring is gekondenseer in pyn. Hierdie psigologiese proses in die samelewing is die keerkant van materiěle veronregting. Met ander woorde, negatiewe ervaring het nie net te doen met materiële manipulasie en eksploitasie nie, maar ook met manipulasie en eksploitasie wat in die psige van die mens plaasvind. Bevryding is dus nie net 'n bevryding van oneweredigheid in materialistiese produksie nie, maar ook die herkenning en erkenning van die pyn op die vlak van die innerlike van die mens. Laasgenoemde negatiewe ervaring, dié wat te doen het met die innerlike van die mens, is dikwels meer versluier as die wat op die 
materiële vlak lê. Die intensiteit van negatiewe psigologiese ervaring is beslis nie minder as dié van negatiewe ervaring wat te doen het met materiële dinge nie, inteendeel. Die feit dat daar pyn en lyding in die wêreld voorkom, beteken dat die samelewing in werklikheid nie is wat die samelewing idealisties van sigself glo nie. Die samelewing hou nie van pyn en lyding nie, want dit bots met die begrip wat die samelewing van sigself het. Daarom is samelewings altyd gereed tot enige strategie wat nood kan teenwerk.

Dit sou dus problematies wees om te wil beweer dat 'n samelewingstruktuur, soos byvoorbeeld die kerk, op enige gegewe comblik nie gereed sou wees om die 'goeie' te implementeer nie. Dit strook nie met bogenoemde dinamiek wat in samelewings (ook in die kerklike samelewing) waarneembaar is nie. 'n Kritiese vraag is of so 'n bewering, wat ten doel het om die status quo (ongeag of dit 'goed' is of nie) te handhaaf, nie dalk in diens staan van magsbelange nie. Hierbo het ek daarop gewys dat dit in die algemeen in die samelewing gaan om die ideaal van 'n verbeterde wêreld. In die kerk gaan die 'goeie' om outentieke lewe voor God. Die 'goeie' in kerk en samelewing wat deur die praktykteoriee in die pastoraat bevorder wil word, hou verband daarmee om in ooreenstemming te wees met wat God wil.

Die teenkanting teen die 'goeie' kan nie aan die samelewing (of kerk) as sodanig toegeskryf word nie. Dit is te wyte aan verwronge kommunikasie wat in menslike interaksie voorkom. Volgens Habermas het simmetriese kommunikasie te doen met sosiale aksie (kyk Dallmayr \& McCarthy 1977:66-72). Wanneer hy oor sosiale' aksie praat, figureer daar altyd verskuilde motiewe onder die oppervlakte. 'Sprekers' ontken egter dat hierdie motiewe hulle bedoeling is. Hier moet ons onthou dat die begrip 'kommunikasie' nie net te doen het met 'n taalhandeling op die linguistiese vlak nie, maar met interaksie tussen mense op alle vlakke. Die motiewe wat so ontken word, lê juis op die pre-linguïstiese vlak. Dit het te doen met geïnstitusionaliseerde vooronderstellings. 'n Voorbeeld hiervan is die patriargale vooronderstelling (vgl Dodson Gray 1982). Hoe meer sulke motiewe onbewustelik in alledaagse kommunikasie oorgedra word, hoe verder is ons van die ideale gespreksituasie. Hierdie afwyking van die ideale gespreksituasie gaan hand aan hand met die toename van die institusionalisering van neerdrukkende maatreëls.

Ons het gesien dat sulke maatreēls aan die een kan verband hou met die vooruitgang van produktiewe kragte op die gebied van ekonomiese en politieke mag. Aan die ander kant hou sulke maatreëls verband met die negatiewe ervaring wat met die innerlike van die mens te doen het. In die modernistiese paradigma was die ekonomiese en politieke mag in die hande van bepaalde rasse en 'n bepaalde geslag. Die sosiale aksie, 
wat Habermas in verband bring met simmetriese kommunikasie, is die aktiwiteit om die negatiwiteit te ontken wat agter institusionalisering lê. Negatiewe ervaring is die gevolg van sulke aktiwiteit.

Die kommunikatiewe handelingsteorie wil kompetensie bevorder. Dit is die bemagtiging van mense wat simmetriese kommunikasie moontlik kan maak. Hierdie bemagtiging bestaan daaruit dat mense daarvan bewus gemaak word dat hulle vanweë institusionalisering geneig is om die motiewe wat sosiale aksie stuur, weg te steek. Hierdie sosiale aksie, gedryf deur negatiewe motiewe, lei tot negatiewe ervaring in die samelewing. Die bewusmaking van hierdie negatiewe motiewe, dit wil sê om weggesteekte eiebelange na die oppervlak te bring, maak dit moontlik om distorsies in die samelewing te herken. Omdat die samelewing gereed is om strategieë te implementeer wat skade en pyn teenwerk, is bewusmaking die sosiale proses wat die 'goeie' kan bevorder en aanmoedig.

Die kommunikatiewe handelingsteorie wil volgens Habermas (in Klemm 1986b: 203-208) egter nie 'bloudrukke' vir die toekoms bied nie. Die teorie vermy utopiese visies. Dit wil vry wees om ook in toekomstige bedelings die ' $k$ waad' wat daar moontlik in die nuwe opset mag skuil, uit te wys. Dié kwaad neem altyd weer die vorm aan van mag oor mense en dinge. Deur eerder ' $n$ bewuswordingsproses aan die gang te sit, hoop en vertrou die kommunikatiewe handelingsteorie om 'n verandering van onder en van binne (beslis nie van bo nie) op dreef te kry. Deur middel van praktyksituasieanalise word 'n self-bewuswording met betrekking tot die verdingliking van mense gekweek. Sodoende kan daar doelbewns gewerk word aan die resultate van die geskiedenis ter wille van 'n verandering van die samelewing in die hede en in die toekoms. So gesien is die ketting van sogenaamde onveranderlike wetmatigheid gebreek. Verandering van die samelewing word dus nie meer geag as 'n outomatiese kousale historiese prosedure nie, maar het die insette van mense nodig. Die geskiedenis as maatskaplike proses word gevolglik nie voltrek bo die koppe van mense heen nie, maar deur die bewuste deelname van mense. Dit is wat bedoel word met 'n epistemologie van deelname.

\section{DEKONSTRUKSIE EN REKONSTRUKSIE}

Die kerk en samelewing wil sigself sien as goed. Teoreties is sowel kerk as samelewing voorstanders van wat goed, reg en regverdig is. Dieselfde kerk en samelewing vertoon egter 'n praktyk wat dikwels in stryd is met hierdie goeie bedoelings. In hierdie studie het ek daarop gewys dat die kritiese kommunikatiewe handelingsteorie die gevolge van so 'n diskrepansie beklemtoon. Vanweè institusionalisering word wat skadelik is in sisteme, 'onsigbaar' en word dit as irrasioneel ervaar omdat mense as gevolg van internalisering daarvan 'onbewus' is. Skadelike elemente in die praktyk 
word nie as sodanig geïdentifiseer nie, maar word gewoon as die vanselfsprekende werklikheid aanvaar.

Die afgelope dekades het stemme van protes begin opklink om kerk en samelewing bewus te maak van die gaping tussen mooi teorieë en minder mooi praktyke. Sedert die sestigerjare het die teologieë van sosiale verandering gegroei. Die term 'politieke teologie' word dikwels hiervoor gebruik. Dit sluit teologieë van ontwikkeling, van revolusie en van bevryding in. In die lig van hierdie ontwikkelings het die vraag na die sosiale verantwoordelikheid van die Christelike geloofsgemeenskap na vore gekom. Die nuwe stemme se poging om 'n verbetering in die praktyk aan te bring, is gefokus op 'n proses van bewuswording. Mense aan die rand van die samelewing word daarvan bewus dat verandering moontlik is en begin beweeg in die rigting van verandering. Die bevryde mens het mag en verantwoordelikheid voor God. In hierdie tipe teologie word aanvaar dat mense nie op 'n deterministiese wyse bepaal word deur die verlede nie, maar vry is om die toekoms tegemoet te tree.

Die tradisionele teologie het nie altyd so positief gereageer op hierdie stemme nie. Die nuwe insigte het egter net weer onderstreep dat elke nuwe era kom met die vrae en perspektiewe van die eie situasie. Die kerk kan nie anders as om voortdurend te reflekteer op die eie verlede en om nuwe weë te bly vind vir die toekoms nie. Wanneer die kerk probeer om nuut te dink in 'n nuwe tyd, is daardie denke kontekstueel bepaald. Mense kan deels bewus word van hierdie kondisionerende faktore en hulle ook gedeeltelik oorstyg. Daar is egter altyd 'n element van konsidionering wat vir mens self onbewus bly. Hier lê die uitdaging vir die kerk. As die geloofsgemeenskap kontekstueel bepaald is en teologiese nadenke nooit anders is as vanuit 'n spesifieke konteks nie, moet daardie konteks verdiskonteer word. Heelheid van menswees bestaan nie kompartementeel uit 'n dichotomie van religieuse heil en sosiale welsyn nie. Heelheid is outentieke menswees en dit het betrekking op die ineengeweefdheid van alle relasies van die mens.

Aangesien alle mense sosiale wesens is wat binne sosiale strukture leef, is die kerk se taak nie net om menslike individue in ontmoeting met God te bring nie, maar om mense in staat te stel om outentiek voor God te lewe. Dit beteken dat ook die sosiokulturele milieu waarbinne gelowiges funksioneer (binne en buite die kerk) vir die kerk van belang is. Alle interpretasie, ook die interpretasie van die Skrif, vind binne in 'n sosio-kulturele konteks plaasvind. Die strukture van kerk, familie, werk en burgerskap vorm persone van kleins af. Hierdie strukture moet ondersoek word. 'n Teologie en kerklike praktyk wat meen om op 'n neutrale wyse, konteksloos te funksioneer, leef in 'n illusie. Om dit voor te gee, is egter in 'n opsig die maklikste uitweg. 'n Kontekslose teologie beteken 'n veilige intellektuele ruimte waar geen ongemaklik praktiese sake gekonfronteer hoef te word nie. 
Die nuwe stemme waarsku teen die 'kanonisering' van enige orde. Vanuit die Reformatoriese perspektief sou dit beteken dat geen mensgemaakte strukture of orde onfeilbaar of volmaak kan wees nie. Waar onvolmaaktheid en skade berokkening aan mense erken en herken word, word dit outomaties 'n Christelike imperatief om dit te bring in die lig van God se woord en dit te verander (bekeer) na God toe. Hierdie nuwe stemme wat begin opklink het, het uitgemond in nuwe wyses van teologiebeoefening. Die sambreelnoemer is 'kontekstuele teologie'. Dit sluit die bevrydingstoologieë in, waaronder ook die feministiese teologieë grotendeels ressorteer. Die leemtes van die bevrydingsteologiee in die algemeen is dat hulle dikwels ' $n$ utopiese trek vertoon en ook dat hulle te direk beweeg van die Skrif na die moderne situasie. Een van die wyses waarop bevrydingsteologiee met skeefgetrekte strukture wil omgaan, is nie om hulle te probeer regtrek nie (hulle word beskou as onherstelbaar), maar om hulle omver te werp. Die strategie is dus revolusie. Die teologiee van revolusie word in eie oë die verlossers wat die euwels in sisteme aandui, en sien revolusie as die enigste manier om van daardie euwels ontslae te raak. Hierdie teologiee wat die tradisionele teologie beskuldig van censydigheid, trap dikwels in dieselfde strik en kyk weer eens net uit een hoek na die menslike situasie.

Die groot wins van hierdie teologiee is egter dat hulle 'n proses van bewusmaking aan die gang gesit het. Hulle het gewaande neutraliteit in teologiebeoefening finaal ontmasker. Dat hulle insigte nie geignoreer kan word nie, is sekerlik duidelik. Die vraag is egter hoe om hierdie insigte op 'n konstruktiewe wyse te inkorporeer. Revolusie as 'n strategie om skadelike praktyke en strukture binne die menslike samelewing reg te stel, lyk om verskeie redes nie geslaagd nie. Dit het dikwels die praktiese geyolg om net 'n vervangende onderdrukkende struktuur daar te stel, met nuwe maghebbers en nuwe slagoffers. Ek het in hierdie artikel bewuswording en bewusmaking bepleit as 'n strategie deur middel waarvan daar op 'n prakties-toepasbare wyse aktief gewerk kan word vir en gestreef kan word na simmetriese interaksie tussen mense binne heilsame strukture. Dit sal uiteraard altyd 'n onverwesenlikte ideaal bly binne die werklikheid van gebroke mense in 'n gebroke wêreld. Aangesien die evangelie die Christen altyd rig na die 'onbereikbare' ideaal, kan ons egter nie, omdat dit klaarblyklik in hierdie wêreld onbereikbaar is, die ideaal laat vaar nie. Inteendeel, biddend om genade en om die werksaamheid van die Heilige Gees, word alle kragte van die gelowige mens ingespan om die ideaal eksistensieel te realiseer - dit beteken om die evangelie se uitnodiging te aanvaar om in te tree in en deel te wees van die koninkryk van God wat Jesus van Nasaret in hierdie wêreld laat realiseer het. Met bewuswording kom die motivering om al hoe meer te leef soos God dit wil. Dit beteken dat gelowiges nooit tevrede kan wees met bestaande strukture nie, tensy hulle werklik eerlik kan glo dat daar geen verbetering nodig is nie. 
Feministiese teoloë is daarvan oortuig dat bestaande strukture wel verbetering nodig het. Hulle sien teologie as 'n belangrike terrein waar die proses van bewusmaking 'n bydrae kan lewer. Die tradisionele teologie veroorsaak egter 'n probleem omdat dit dikwels gedomineer word deur patriargale beelde van en vir God. In die tadisionele teologie word daar soms 'n karikatuur van vroue gemaak of is vroue eenvoudig onsigbaar en word ongesonde, kultureel-gekondisioneerde geslagsrolle vir vroue versterk. Die patriargale denksisteem inherent aan die tradisionele teologie word dus deur feministiese teoloë, mans en vroue, bevraagteken. Soos voorheen aangetoon, word verskillende strategiee hiermee gevolg.

Daar is vroeèr aangedui dat 'n revolusionêre hantering van distorsies in die kerk en samelewing bloot lei tot die omkeer van dominerende rolle. Teenoor hierdie moontlike strategie verkies ek 'n strategie van bewuswording en bewusmaking. Wat Skrifbeskouing betref, steun ek nie ' $n$ monolitiese siening nie. Ek is van mening dat post-moderne dekonstruksie wat kan help om aan te toon dat opponente se stem stil gemaak word deur ostrasering en marginalisering, ' $n$ hermeneutiese wins is. Ek is gekant teen 'n reaksie wat lei tot 'n volgende eensydigheid. Ek meen nie dat tekste gelees móét word net soos dit voor die leser lê nie, hoewel hedendaagse literatuurteoretiese immanente leesstrategiee 'n belangrike bydrae tot eksegese gelewer het. Om die wins van driehonderd jaar se historiese kritiek egter nou te ignoreer, lyk ook nie wenslik nie.

Die historiese kritiek het ons in staat gestel om met diachroniese leesstrategieë nie net tradisies agter tekste te herken nie, maar ook om die redaksionele tendense in die verwerkings van tradisies raak te sien. Aangevul met die post-moderne insig in die rol wat ideologieë gespeel het in die vorming van hierdie tendense, is dit nou vir ons moontlik om te onderskei tussen elitistiese meesternarratiewe en kontranarratiewe wat daarteen protesteer. Die bewussyn dat die geskiedenis ons leer dat 'n kontranarratief die potensiaal het om self weer 'n meesternarratief te word, makk 'n mens uiters bedag op blinde eensydigheid (kyk Breytenbach 1997:1166, 1172). Alle diskoerse moet daarom voortdurend vanuit ' $n$ hermeneutiek van suspisie benader word. My klem op bewusmaking en bewuswording van distorsies bring mee dat ek in betrokke hermeneutiek twee dinge wil verdiskonteer: ' $n$ norm wat die inhoud van tekste sal booordeel in die lig van 'God se bedoeling' wat 'n spesifieke Christelike inhoud het en 'n epistemologie wat nie kragteloos gemaak word deur 'n reduserende, positivistiese objektiwisme of determinisme nie.

\section{Literatuurverwysings}

Ackermann, D 1993. Liberating the word: Some thoughts on feminist hermeneutics Scriptura 44, 1-18. 
Barth, K [1932] 1964. Die Heilige Schrift, in Die kirchliche Dogmatik, Erster Band, Zweiter Teil. (Erstes Kapitel: Die Wort Gottes als Kriterium der Dogmatik, Erster Halbband), 47-310. 8.Aufl. Zürich: EVZ Verlag.

- Die Heilige Schrift, in Die kirchliche Dogmatik, Erster Band, Zweiter Teil. (Drittes Kapitel: Die Lehre vom Wort Gottes. Prolegomena zur kirchliche Dogmatik, Zweiter Halbband), 505-830. Zollikon-Zürich: Evangelischer Verlag.

Beukes, C J 1996. Michel Foucault en die historisering van Anderswees. HTS 52/2 \& 3, 233-251.

Breytenbach, A P B 1997. Meesternarratiewe, kontranarratiewe en kanonisering - 'n Perspektief op sommige profetiese geskrifte. HTS 53/4, 1157-1182.

Dallmayr, F R \& McCarthy, T A 1977 . Understanding and social enquiry. Notre Dame: University of Notre Dame Press.

Daly, M 1973. Beyond God the Father: Toward a philosophy of women's liberation.

Boston: Beacon.

- 1979. Gyn/Ecology: The metaethics of radical feminism. Boston: Beacon.

De Pater, W A 1996. Het postmoderne nog eens uitgelegd. Nederlands Theologisch Tijdschrift 50/3, 177-202.

Dodson Gray, E 1982. Patriarchy as a conceptual trap. Wellesley, MA: Roundtable Press.

Donoghue, D 1996. Emmanuel Levinas: The philosopher of selfless love. The New York Review (March 21), 37-40.

Elliott, J H 1993. What is social scientific criticism? Minneapolis: Fortress.

Engelsman, J C 1979. The feminine dimension of the divine. Philadelphia: Westminster.

Eriksson, A-L 1994. The meaning of gender in theology: Problems and possibilities. Stockholm: Gotab. (Women in Religion 6.)

Fiorenza, F 1989. Die Kirche als Interpretationsgemeinschaft: Politische Theologie zwischen Diskursethik und hermeneutischer Rekonstruktion, in Arens, E (Hrsg), Habermas und die Theologie, 115-144. Düsseldorf: Patmos Verlag.

Foh, S T 1979. Woman and the Word of God: A response to Biblical feminism. Philadelphia: Presbyterian and Reformed Publishing Company.

Gadamer, H-G [1960] 1994. Truth and method. Second revised edition. Translation revised by J Weinsheimer \& D G Marshall. New York: Continuum.

Habermas, J [1970] 1981. Towards a theory of communicative competence, in Klemm, 1986b: 221-223.

Habermas, J [1981] 1984. The theory of communicative action, Vol I: Reason and the rationalization of society, to by $\mathrm{T}$ McCarthy. Boston: Beacon. 
Klemm, D E 1986a. Introduction to Habermas' On systematically distorted communication and Toward a theory of communicative competence, in Klemm, D E (ed), Hermeneutical inquiry, Vol 2: The interpretation of existence, 203-208. Atlanta: Scholars Press. (AAR Studies in Religion.)

- (ed) 1986b. Hermeneutical inquiry, Vol 2: The interpretation of existence, 203-208. Atlanta: Scholars Press. (AAR Studies in Religion.)

Maddox, R L 1985. Contemporary hermeneutic philosophy and theological studies. Religious Studies 21/4, 517-529.

Marsh, C 1997. Quests of the historical Jesus in new historicist perspective. Biblical Interpretation 5/4, 403-437.

Mouton, J 1987. Die positivisme, in Snyman, JJ \& Du Plessis P G W (reds), Wetenskapsbeelde in die geesteswetenskappe, 1-29. Pretoria: RGN. (RGN-Studies in Navorsingsmetodologie 3.)

Osiek, C 1997. The feminist and the Bible: Hermeneutical alternatives. HTS 53/4, 955-967.

Pelser, G M M 1992. Bybelse hermeneutiek: Van die vroeè kerk tot die nuwe hermeneutiek. Ongepubliseerde studiehandleiding, Departement Nuwe-Testamentiese Wetenskap (Afd A), Universiteit van Pretoria.

Peukert, H 1989. Kommunikatives Handeln, Systeme der Machtsteigerung und die unvollendeten Projekte Aufklärung und Theologie, in Arens, E (Hrsg), Habermas und die Theologie, 39-64. Düsseldorf: Patmos Verlag.

Pieterse, H J C 1979. Skrifverstaan en prediking: Die verhouding van Woordgebeure en verstaansgebeure by Gerhard Ebeling as antwoord op die nood van die prediking. Pretoria: NG Kerkboekhandel.

Romm, N 1987. Habermas se wetenskapsteorie, in Snyman \& Du Plessis 1987:179197.

Ruether R R 1975. New woman/New earth: Sexist ideologies and human liberation. New York: Seabury.

1983. Sexism and God-talk: Toward a feminist theology. Boston: Beacon.

Schüssler Fiorenza, E 1985. In memory of her: A feminist theological reconstruction of Christian origins. New York: Crossroad.

— E 1992. But she said: Feminist practices of biblical interpretation. Boston: Beacon.

Snyman, J J 1987. Die wetenskapsopvatting van die Frankfurtse Skool, in Snyman \& Du Plessis 1987:155-177.

Swidler, L J 1979. Biblical affirmations of woman. Philadelphia: Westminster. 
Tavard, G H 1973. Woman in Christian tradition. Notre Dame, IN: University of Notre Dame Press.

Thiselton, A C 1980. The two horizons: New Testament hermeneutics and philosophical description with special reference to Heidegger, Bultmann, Gadamer and Wittgenstein. Grand Rapids: Eerdmans.

Tolbert, M A 1990. Protestant feminists and the Bible: On the horns of a dilemma, in The pleasure of her text: Feminist readings of biblical and historical texts. Philadelphia: Trinity Press International.

Trible, P 1978. God and the rhetoric of sexuality. Philadelphia: Fortress. (Overtures to Biblical Theology.)

1984. Texts of terror: Literary-feminist readings of biblical narratives. Philadelphia: Fortress. (Overtures to Biblical Theology 13.)

1994. Rhetorical criticism: Context, method and the book of Jonah. Minneapolis: Fortress. (Guides tot Biblical Scholarship. Old Testament Series.)

Van Aarde, A G 1994. The epistemic status of the New Testament and the emancipatory living of the historical Jesus in engaged hermeneutics. Neotestamentica 28/2, $1-25$.

Vorster W S 1988. Towards a post-critical paradigm: Progress in New Testament scholarship, in Mouton, J, Van Aarde, A G \& Vorster, W S (eds), Paradigms and progress in theology, 31-48. Pretoria: HSRC. (HSRC Studies in Research Methodology 5.)

Vos, C J A 1996a. Die volheid daarvan, 1: Homiletiek uit 'n hermeneuties-kommunikatiewe perspektief. Pretoria: RGN.

1996b. Die wolheid daarvan, 2: Homiletiek uit 'n hermeneuties-kommunikatiewe perspektief. Pretoria: RGN.

Weber, O [1963] 1967. Karl's Barth's Kirchliche Dogmatik: Ein einfuhrender Bericht. 6.Aufl. Neukirchen-Vluyn: Neukirchener Verlag.

Zahmt, H [1966] 1967. Die Sache mit Gott: die protestanticche Theologie im 20. Jahrhundert. München: R Piper \& Co. Verlag. 